James, U. (1959). Ibid., 2, 1001.

Lincoln, K., and Winberg, J. (1964). Acta paediat. (Uppsala), 53, 307.

Loudon, I. S. L., and Greenhalgh, G. P. (1962). Lancet, 2, 1246.

Mond, N. C., Percival, A., Williams, J. D., and Brumfitt, W. (1965). Ibid., 1, 514.

Neumann, C. G., and Pryles, C. V. (1962). Amer. F. Dis. Child., 104, 215 .

Porter, K. A., and Giles, H. McC. (1956). Arch. Dis. Childh., 31, 303.
Rupp, W. (1958). Z. Kinderheilk., 81, 200.

Sauer, L. W. (1925). F. Amer. med. Ass., 85, 327.

Slater, E. (1962). Lancet, 1, 69.

Smellie. Hodson, C. J., Edwards, D., and Normand, I. C. S (1964). Brit. med. 于े., 2, 1222.

Stansfeld, J. M. (1954). Proc. roy. Soc. Med., 47, 631.

Stansfeld, J. M. (1954). Proc. roy. Soc.

Woodruff, J. D., and Everett, H. S. (1954). Amer. F. Obstet. Gynec., 68, 798.

\title{
Relapses of Urinary-tract Infections in Children
}

\author{
J. M. STANSFELD,* M.A., M.D.
}

Brit. med. F., 1966, 1, 635-637

It is one thing to clear the urine of a child with a urinary-tract infection but quite another to keep it clear, and relapses are both common and ill-understood. This paper records their frequency, connexion with treatment, and time of occurrence in a group of 350 children with urinary-tract infections. The cases were seen at two hospitals, and details, including sex, age, and incidence of anatomical abnormalities, are given elsewhere (Stansfeld, 1966). All have been kept under continued observation. After initial hospitalization the children were at first seen every one or two months, but later the intervals were lengthened up to a year, depending on the progress in each case. The period of observation, average number of times seen, and frequency of visits are given in Table I. Treatment has varied over the years, but antibiotics have been selected throughout in accordance with the sensitivity of the organisms recovered from the urine and usually given in full dosage for one or two weeks followed by a reduced amount given for months or even years. Surgical relief of obstructive lesions has been undertaken whenever possible, and most cases have been seen at a combined medical and surgical clinic.

TABLE I.-Details of Follow-up of 350 Cases of Urinary-tract Infection in Children

\begin{tabular}{|c|c|c|c|c|c|c|}
\hline & \multirow{2}{*}{$\begin{array}{l}\text { No. } \\
\text { of } \\
\text { Cases }\end{array}$} & \multirow{2}{*}{$\begin{array}{l}\text { Observed } \\
\text { less than } \\
6 \text { Months }\end{array}$} & \multicolumn{2}{|c|}{$\begin{array}{c}\text { Monthly } \\
\text { under } \\
\text { Observation }\end{array}$} & \multirow{2}{*}{$\begin{array}{c}\text { Average } \\
\text { No. Times } \\
\text { Seen }\end{array}$} & \multirow{2}{*}{$\begin{array}{l}\text { Average } \\
\text { Interval } \\
\text { between } \\
\text { Visits } \\
\text { (Months) }\end{array}$} \\
\hline & & & Range & Average & & \\
\hline $\begin{array}{cc}\text { Hospital } & \mathrm{A} \\
\geqslant & \mathrm{B}\end{array}$ & $\begin{array}{l}193 \\
157\end{array}$ & $\begin{array}{l}25 \\
19\end{array}$ & $\begin{array}{l}1-131 \\
1-178\end{array}$ & $\begin{array}{l}27 \frac{3}{4} \\
44\end{array}$ & ${ }_{9 !}^{10}$ & $\begin{array}{r}2 \frac{3}{3} \\
4 \frac{3}{4}\end{array}$ \\
\hline
\end{tabular}

A relapse or a reinfection-no distinction has been made between these two-has been taken to be a return of significant pyuria or bacilluria, with or without symptoms, after the urine had previously been clear. In a few cases infection could not be controlled, and though there might be exacerbations these were not counted as relapses. Some who had responded to treatment became unwell between their visits to the hospital, and, without their urine being examined, had further treatment from their family doctors and thus were well again when they returned to the follow-up clinic. Whether these episodes were relapses or not was decided on the history of the symptoms and the special knowledge the family doctor and the mother had of the child. When there was any doubt treatment was stopped and the child was watched to see what happened. No attempt was made to number the relapses which had occurred before the child was first seen in hospital, but they were known to be frequent.

* Consultant Paediatrician, Durham and North-west Durham Hospital Management Committees ; Associate Physician, Child Health Department, the Royal Victoria Infirmary, Newcastle upon Tyne.

\section{Relapse Rate}

In 28 of the 350 cases treatment failed. In spite of all that was done their pyuria and bacilluria continued unabated. All these patients had gross abnormalities of the urinary tract, such as severe obstruction or paralysed bladder, and the six deaths in the series occurred among them. The remaining 322 responded to treatment, with clearing of their urine, for at least two months. Yet many had relapses (Table II).

TABLE II.-Relapses Encountered Among 350 Children with Urinarytract Infections

\begin{tabular}{|c|c|c|c|c|c|c|c|c|c|}
\hline & \multirow{2}{*}{$\begin{array}{l}\text { Total } \\
\text { Cases }\end{array}$} & \multicolumn{7}{|c|}{ No. of Relapses } & \multirow{2}{*}{$\begin{array}{l}\text { Persistent } \\
\text { Infection } \\
\text { or Death }\end{array}$} \\
\hline & & 0 & 1 & 2 & 3 & 4 & 5 & 6 & \\
\hline $\begin{array}{c}\text { Hospital } \\
\text { A }\end{array}$ & $\begin{array}{l}193 \\
157\end{array}$ & $\begin{array}{r}94 \\
108\end{array}$ & $\begin{array}{l}48 \\
17\end{array}$ & $\begin{array}{r}18 \\
9\end{array}$ & 11 & $\begin{array}{l}6 \\
5\end{array}$ & $\begin{array}{l}1 \\
2\end{array}$ & $\begin{array}{l}1 \\
0\end{array}$ & $\begin{array}{l}14 \\
14\end{array}$ \\
\hline
\end{tabular}

Apart from suggesting that relapses are common the figures in Table II give no indication of their true frequency, which will obviously depend upon how long each case is observed. Taking into account the length of follow-up in each case, the rates for first relapses were worked out in a life-table, from which Table III is derived. This shows how many relapses occurred in each 100 cases during six-monthly intervals over a period of three years after initial control. Many relapsed during the first 18 months, and this should be the minimum follow-up period for all cases. The figures also illustrate how greatly the results at one hospital may differ from those at another. The treatment at the two hospitals concerned was very similar but the cases were quite different. Those at hospital A, a teaching hospital, were referred from a wide area and sent because of anatomical abnormality or because they were not responding to hospital treatment elsewhere, while those at hospital $\mathrm{B}$ were solely referred by family doctors.

Table III.-Relapse Rate Per 100 Cases at Intervals After Initial Onset

\begin{tabular}{|c|c|c|c|c|c|c|c|}
\hline \multirow{2}{*}{$\begin{array}{l}\text { 6-month } \\
\text { period: }\end{array}$} & \multicolumn{2}{|c|}{ 1st Year } & \multicolumn{2}{|c|}{ 2nd Year } & \multicolumn{2}{|c|}{ 3rd Year } & \multirow{2}{*}{$\begin{array}{l}\text { Total } \\
\text { for } \\
3 \text { Years }\end{array}$} \\
\hline & First & Second & Third & Fourth & Fifth & Sixth & \\
\hline $\begin{array}{cc}\text { Hospital } & \text { A } \\
\text {, } & \text { B }\end{array}$ & $\begin{array}{r}19 \cdot 6 \\
9 \cdot 4\end{array}$ & $\begin{array}{r}13 \cdot 1 \\
3 \cdot 1\end{array}$ & $\begin{array}{r}13 \cdot 0 \\
9 \cdot 2\end{array}$ & $\begin{array}{l}5 \cdot 4 \\
2 \cdot 6\end{array}$ & $\begin{array}{l}3 \cdot 2 \\
1.5\end{array}$ & $1 \cdot 3$ & $\begin{array}{l}55 \cdot 6 \\
25 \cdot 8\end{array}$ \\
\hline Combined .. & $14 \cdot 8$ & $8 \cdot 3$ & $11 \cdot 2$ & $3 \cdot 8$ & $2 \cdot 2$ & 1.0 & $41 \cdot 3$ \\
\hline
\end{tabular}

\section{Time and Cause of Relapses}

About $40 \%$ of the relapses occurred during treatment and $60 \%$ after it had stopped. Those during treatment were mostly of unknown cause or due to the presence of resistant organisms, some were due to the child failing to take his medicine or pills, 
some followed respiratory-tract infections, and a few came after cystoscopy or catheterization (Table IV). They occurred in $15 \%$ of treatments and were no more frequent in the first than in subsequent courses. It seemed that they were more likely to happen early in treatment than later, but this was because there were more cases at risk for shorter treatments, and when the true relapse rates were determined by relating relapses to the numbers at risk for each length of treatment it was found that relapses were no commoner at the beginning than later (Table $\mathrm{V})$. Indeed, the distribution of relapses during the first 14 months of treatment was not significant $\left(\chi^{2}=10.28, \mathrm{n}=13\right.$, $0.7>\mathrm{P}>0.5$ )

\begin{tabular}{|c|c|c|c|c|c|}
\hline & Unknown & $\begin{array}{c}\text { Resistant } \\
\text { Organisms }\end{array}$ & $\begin{array}{l}\text { Failure } \\
\text { to take } \\
\text { Medicine } \\
\text { or Pills }\end{array}$ & $\begin{array}{c}\text { Respiratory } \\
\text { Infection }\end{array}$ & $\begin{array}{l}\text { Instru- } \\
\text { mentation }\end{array}$ \\
\hline $\begin{array}{l}\text { During treatment (95 } \\
\text { relapses) . } \\
\text { After treatment }(128 \\
\text { relapses) } \ldots\end{array}$ & $\begin{array}{r}30 \\
101\end{array}$ & $\begin{array}{r}36 \\
4\end{array}$ & $\begin{array}{l}16 \\
-\end{array}$ & $\begin{array}{l}10 \\
19\end{array}$ & $\begin{array}{l}3 \\
4\end{array}$ \\
\hline
\end{tabular}

TABLE V.-Relapses During Treatment-Time of Occurrence

\begin{tabular}{c|c|c|c}
$\begin{array}{c}\text { Duration of } \\
\text { Treatment } \\
\text { (Months) }\end{array}$ & No. at Risk & Relapses & $\begin{array}{c}\text { Percentage } \\
\text { Relapse } \\
\text { Rate }\end{array}$ \\
\hline-1 & 421 & 9 & $2 \cdot 1$ \\
-2 & 350 & 6 & $1 \cdot 7$ \\
-3 & 315 & 9 & $2 \cdot 9$ \\
-4 & 270 & 13 & $4 \cdot 8$ \\
-5 & 245 & 6 & $2 \cdot 4$ \\
-6 & 222 & 6 & $2 \cdot 7$ \\
-7 & 212 & 7 & $3 \cdot 3$ \\
-8 & 177 & 5 & $2 \cdot 8$ \\
-9 & 156 & 2 & $1 \cdot 3$ \\
-10 & 139 & 3 & $2 \cdot 0$ \\
-11 & 118 & 4 & $0 \cdot 4$ \\
-12 & 105 & 1 & $1 \cdot 2$ \\
-13 & 81 & 1 & $2 \cdot 8$ \\
-14 & 71 & 2 & \\
\hline
\end{tabular}

Four out of five of the relapses which occurred after treatment had stopped were unexplained. Like those during treatment, a few followed respiratory infections and some occurred after instrumentation, but fewer were associated with organisms resistant to the drugs which had last been given (Table IV). When the off-treatment relapses were related to the duration of follow-up it was clear that the relapse rate was highest immediately after stopping treatment and then fell steadily (Table VI). The diminishing frequency of relapses during the first 14 months after treatment had been discontinued was unlikely to be a chance finding $\left(x^{2}=26.6, n=13,0.02>P>0.01\right)$. A practical point which emerges is that cases should be seen frequently and at least at monthly intervals during the period immediately after treatment has been stopped, for it is then that relapses are most likely to occur.

\begin{tabular}{|c|c|c|c|}
\hline $\begin{array}{l}\text { Time after } \\
\text { Treatment } \\
\text { (Months) }\end{array}$ & No. at Risk & Relapses & $\begin{array}{c}\text { Percentage } \\
\text { Relapses } \\
\text { Rate }\end{array}$ \\
\hline $\begin{array}{r}-1 \\
-2 \\
-3 \\
-4 \\
-5 \\
-6 \\
-7 \\
-8 \\
-99 \\
-10 \\
-11 \\
-12 \\
-13 \\
-14 \\
\text { Over } 14\end{array}$ & $\begin{array}{l}326 \\
279 \\
255 \\
240 \\
226 \\
208 \\
190 \\
176 \\
168 \\
160 \\
151 \\
145 \\
135 \\
130\end{array}$ & $\begin{array}{r}18 \\
17 \\
12 \\
9 \\
7 \\
6 \\
4 \\
5 \\
4 \\
3 \\
2 \\
0 \\
2 \\
1 \\
16\end{array}$ & $\begin{array}{l}5.5 \\
6.0 \\
5.8 \\
3.7 \\
3.1 \\
2.9 \\
2.1 \\
2.8 \\
2.4 \\
1.9 \\
0.7 \\
0.7 \\
0.8\end{array}$ \\
\hline
\end{tabular}

The occasional association of relapses with respiratory infections both during and after treatment prompted a further analysis to discover if the relapses, like respiratory infections, occurred more often in the winter months. This seemed to be the case. The monthly incidence of relapses is given in Table VII. The maximizing dichotomy was made by comparing the winter half-year November-April with MayOctober, the difference being significant at $1 \%$ level (David and Newell, 1966).

$$
\text { TABLE VII.-Distribution of Relapses by Months }
$$

\begin{tabular}{l|l|l|l|l|l|l|l|l|l|l|l|l|l|l}
$\begin{array}{l}\text { Month } \\
\begin{array}{c}\text { No. of } \\
\text { relapses }\end{array}\end{array}$ & 14 & 24 & 16 & 20 & 11 & 12 & 13 & 11 & 7 & 8 & 23 & 13 & 51 & 223 \\
* Unknown or relapse due to instrumentation.
\end{tabular}

\section{Relapses and Duration of Treatment}

One of the difficulties in dealing with children who have urinary-tract infections is to decide the length of the treatment. Should it last only for a few days or go on for weeks, months, or even years? It is doubtful if anybody knows the answer. Cases differ too greatly to allow satisfactory comparison of different lengths of treatment. Urinary-tract infection, particularly in children, is a disease of subgroups. Age at onset, sex, length of history, previous relapses, and type of organism, as well as the presence or not of any number of functional or structural abnormalities in the renal tract, may influence the response to treatment. Scarcely two cases are alike.

It must be admitted that analysis of this series of cases gave little guidance with regard to length of treatment. "Failures" and "successes" were compared for duration of treatment, but there were difficulties. Relapses which occurred within two months after treatment had been discontinued were regarded as failures, whereas patients who remained well during a minimum of six months' follow-up were counted as successes. Both were related to first treatments, since for those who had multiple treatments it was difficult to decide if the duration of treatment should refer only to the last or to the total number of treatments.

Defined in these terms there were 36 failures and 93 successes in the series. Even these could not properly be compared, since there were other differences between the two groups than the length of the treatment. Thus the failures had longer histories, and more often had anatomical defects requiring surgical intervention. The groups had to be further reduced so that only non-surgical cases with similar durations of history were compared. This gave a total of 18 failures to be compared with 74 successes. These are shown in the Chart, and are grouped by their length of history and spaced out according to the length of treatment they received. Some clustering of failures appears to occur in the left lower corner, suggesting that for those with long histories anything less than three months' treat-

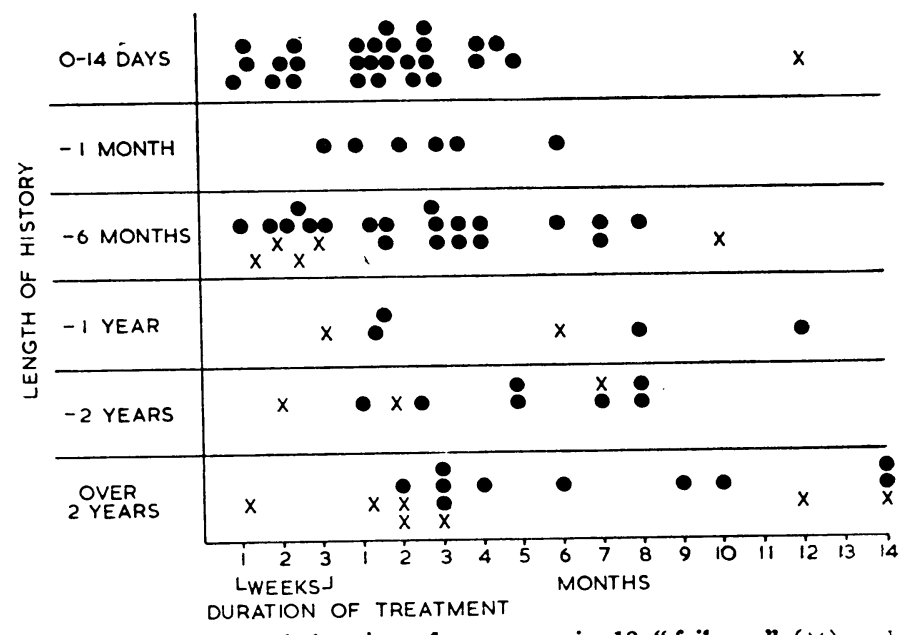

Length of history and duration of treatment in 18 "failures" $(X)$ and 74 " successes" (O). 
ment is inadequate. As a rough guide for non-surgical cases treatment given over a period equal to the length of the history would in most cases have been adequate.

\section{Summary}

A group of 350 children with urinary-tract infection have been kept under continued surveyance. The infections were not controlled in 28 cases, all of which had major renal-tract abnormalities. The remaining 322 responded to treatment but had a high relapse rate, particularly during the first 18 months after initial control.

During treatment relapses might occur at any time, and many were associated with resistant organisms or the child's failure to take the prescribed medicine or pills. Relapses after treatment had stopped were usually unexplained, but were most likely to occur within the first three months.
Thirteen per cent. of all relapses were associated with upper respiratory infections. Relapses were significantly more frequent during the winter half-year, November to April, than in the summer.

There was some suggestion that for non-surgical cases with a history of over two years' duration anything less than three months' treatment was inadequate.

I would like to thank Professor S. D. M. Court for his help and interest. I am grateful to Mr. R. A. McNay for advice concerning the statistical analysis and to Mrs. M. Jackson for editorial assistance.

\section{REFERENCES}

David, H. A., and Newell, D. J. (1966). Biometrics. In press. Stansfeld, J. M. (1966). Brit. med. F., 1, 631.

\title{
Further Trials of Live Influenza Vaccine*
}

\author{
B. E. ANDREWS, $†$ M.R.C.S., M.C.PATH., DIP.BACT. ; A. S. BEARE, $\ddagger$ M.B., B.CH., M.C.PATH., D.T.M.\&H. \\ J. C. MCDONALD,§\| M.D., M.SC., M.R.C.P., D.P.H. ; A. J. ZUCKERMAN,\$』 M.D., M.SC., M.C.PATH., DIP.BACT. \\ D. A. J. TYRRELL, $* *$ M.D., F.R.C.P., M.C.PATH.
}

Brit. med. F., 1966, 1, 637-640

Small-scale trials of a live influenza $A_{2}$ vaccine in 1960-1 showed that symptomless infections were induced in most subjects, and that despite a rather poor antibody response the volunteers could not be reinfected a month later (McDonald et al., 1962). The vaccine used in these trials was prepared from the Russian $\mathrm{A}_{2}$ strain Iksha attenuated by serial passage in eggs, and was given by drops intranasally. It was therefore pertinent to investigate whether other $A_{2}$ strains would have similar properties if treated in the same way and to investigate whether the vaccine could be given equally well by spray. At the same time we thought it important to determine whether inactivated virus, given intranasally, has any effects (Przesmycki et al., 1959). Vaccines were prepared from the Iksha strain and from a Scottish strain of $A_{2}$ virus, $A / S \cot / 49 / 57$, and their efficacy compared in volunteers.

\section{Technical Procedures}

\section{Preparation of Vaccines and Preliminary Safety Tests}

The live vaccines were prepared in a similar way. The virus was inoculated into the allantoic cavity of 10-day-old chick embryos and these were incubated at $33^{\circ} \mathrm{C}$. for two days. The fluids were harvested and stored at $-70^{\circ} \mathrm{C}$. in glass ampoules. The fluids were tested for the presence of contaminating bacteria by aerobic and anaerobic culture and for viruses (a) by inoculating tissue cultures after mixture with ferret immune serum against $\mathrm{A} /$ Singapore $/ 1 / 57$, and $(b)$ by inoculating into mice by the intracerebral and intranasal route, into guinea-pigs by the

* A report to the Medical Research Council Committee on Influenza and other Respiratory Virus Vaccines.

† Virus Reference Laboratory, Colindale, London.

Epidemiological Research Laboratory, Colindale, London.

** Common Cold Research Unit, Salisbury.

$¥$ Present address, Pfizer Group, Sandwich, Kent.

II Professor of Epidemiology and Health, McGill University, Montreal.

If Seconded from the R.A.F. Medical Services at the time of the trial. Present anpointment: Senior Lecturer, London School of Hygiene and Tropical Medicine, London. intracerebral route, and into rabbits by the subcutaneous route. All the animals remained well. The viruses showed specific haemagglutination-inhibition with ferret immune serum that had been treated with cholera filtrate to remove non-specific inhibitors.

The Iksha strain had been passed six times in ovo and had a titre of $10^{8.2} 50 \%$ egg-infectious doses $\left(\mathrm{EID}_{50} / \mathrm{ml}\right.$.), while the A/Scot/49/57 strain had received about five such passages and had a titre of $10^{9} \mathrm{EID}_{50} / \mathrm{ml}$. A portion of the Iksha virus was inactivated by dialysing it against distilled water and then adding $0.025 \%$ formalin and storing at $4^{\circ} \mathrm{C}$. The virulence for man of the A/Scot/49/57 virus was roughly gauged by administering it in doses of $10^{6}$ and $10^{7} \mathrm{EID}_{50}$ to two groups of four volunteers living in isolation. Three of those given the larger dose developed symptoms, but only one of those given the smaller; it was considered safe to give doses of less than $10^{6} \mathrm{EID}_{50}$ to larger numbers of subjects.

As both the strains gave low titres of inhibition with horse serum, a further strain, A/Eng/443/57, which is very sensitive to inhibitors, was also tested. This produced such marked symptoms in a small group of isolated volunteers that it was not studied further.

The live vaccines were stored in sealed glass ampoules in an electric refrigerator at $-70^{\circ} \mathrm{C}$. until transported to the station on solid carbon dioxide. The vaccine was diluted with Hanks's balanced salt solution containing $0.5 \%$ gelatin $(p H$ about 7.2) immediately before use and kept at $4^{\circ} \mathrm{C}$. until used; this period never exceeded 30 minutes. The dose of vaccine intended for nasal drops was made up to $1 \mathrm{ml}$. with diluent, whereas for spray it was suspended in $0.1 \mathrm{ml}$.

\section{Virus Isolation}

Specimens from nose and throat swabs, prepared as described below, were transported to the laboratory on melting ice, and on the same day $0.2 \mathrm{ml}$. was inoculated into the amniotic cavity 